Fish \& Shellfish Immunology

October 2015, Volume 46, Issue 2, Pages 703-709

http://dx.doi.org/10.1016/i.fsi.2015.08.007

http://archimer.ifremer.fr/doc/00275/38617/

(c) 2015 Elsevier Ltd. All rights reserved.

\title{
Vitamin A supplementation enhances Senegalese sole (Solea senegalensis) early juvenile's immunocompetence: new insights on potential underlying pathways
}

\author{
Fernández Ignacio ${ }^{1,2,{ }^{*} \text {, Lopez-Joven Maria-Carmen }}{ }^{2,3}$, Andree Karl B. ${ }^{2}$, Roque Ana ${ }^{2}$, Gisbert Enric ${ }^{2}$ \\ ${ }^{1}$ Centro de Ciências do Mar (CCMAR/CIMAR-LA), Universidade do Algarve, Campus de Gambelas, \\ 8005-139 Faro (Portugal) \\ ${ }^{2}$ IRTA, Centre de Sant Carles de la Ràpita (IRTA-SCR), Unitat de Cultius Experimentals, Crta. del \\ Poble Nou s/n, 43540 Sant Carles de la Ràpita (Spain) \\ ${ }^{3}$ Interactions Hôtes-Pathogènes-Environnements (IHPE, UMR 5244), Ifremer, CNRS, University of \\ Montpellier, University of Perpignan Via Domitia, Place Eugène Bataillon, CC80, 34095 Montpellier \\ cedex 5, France \\ * Corresponding author : Ignacio Fernández, Tel.: +34 977745427 ; fax: +34 977443138 ; \\ email addresses : nacfm@hotmail.com ; ivmonzon@ualg.pt ; \\ Web address : http://www.ccmar.ualg.pt/edge/
}

\begin{abstract}
:
Senegalese sole (Solea senegalensis) has been considered since the 1990's to be a promising flatfish species for diversifying European marine aquaculture. However, pathogen outbreaks leading to high mortality rates can impair Senegalese sole commercial production at the weaning phase. Different approaches have been shown to improve fish immunocompetence; with this in mind the objective of the work described herein was to determine whether increased levels of dietary vitamin A (VA) improve the immune response in early juveniles of Senegalese sole. For this purpose, Senegalese sole were reared and fed with Artemia metanauplii containing increased levels of VA $(37,000 ; 44,666 ; 82,666$ and 203,000 total VA IU Kg${ }^{-1}$ ) from 6 to 60 days post-hatch (early juvenile stage). After an induced bacterial infection with a $50 \%$ lethal dose of Photobacterium damselae subsp. damselae, survival rate, as well as underlying gene expression of specific immune markers (C1inh, C3, C9, Lgals1, Hamp, LysC, Prdx1, Steap4 and Transf) were evaluated. Results showed that fish fed higher doses of dietary VA were more resistant to the bacterial challenge. The lower mortality was found to be related with differential expression of genes involved in the complement system and iron availability. We suggest that feeding metamorphosed Senegalese sole with 203,000 total VA IU Kg ${ }^{-1}$ might be an effective, inexpensive and environmentally friendly method to improve Senegalese sole immunocompetence, thereby improving survival of juveniles and reducing economic losses.
\end{abstract}




\section{Highlights}

- Dietary vitamin A (VA) enhances immune system in Solea senegalensis juveniles. Sole fed 203,000 VA IU Kg${ }^{-1}$ had higher resistance to an induced bacterial infection. Complement system and iron homeostasis genes were differentially expressed. Dietary VA levels impact on the fish osteoimmunological response.

Keywords: vitamin, retinoic acid, immune system, gene expression, Senegalese sole Solea senegalensis, Photobacterium damselae subp. damselae 
1. Introduction

50 Diversification of marine aquaculture is a major issue, with Senegalese sole (Solea senegalensis) being one of the most promising species for aquaculture diversification in the Iberian Peninsula [1]. As recently reviewed [1], an increased understanding has been obtained on the manner in which husbandry practices, environmental conditions (such as rearing temperature, salinity, light spectrum and intensity), genetic background and/or nutrition influences fish physiology. However, despite this research effort, multiple bottlenecks like resistance to pathogen infection, outbreaks of infectious disease, incidence of skeletal deformities, and impaired reproductive performance in captivity still exist [1].

In Senegalese sole farms, a wide array of pathogens has been detected [2], which are commonly treated with antibiotics and/or chemotherapeutics. In particular, Photobacterium damselae subsp. piscicida (Phdp), the aetiologic agent of fish pasteurellosis, induces economic losses [3] and thus, has received significant attention. In contrast, less is known regarding $P$. damselae subsp. damselae (Phdd), although it is an emerging pathogen in marine aquaculture [4]. are being sought. In this context, probiotics as well as other immunomodulatory substances like vitamins, minerals and amino acids seem to offer an attractive alternative $[5,6]$ to chemotherapies. Vitamin A (VA), and its derivatives (retinoids), have pleiotropic roles. Since fish are not able to synthezise VA compounds de novo, they have to acquire them from the diet. Their excess or deficiency cause abnormal development/homeostasis in different tissues, organs and/or systems [7]. In particular, VA is widely known to promote the mammalian immune response [8], although the mechanism by which VA effects thisis still not clearly understood. In different fish species, several VA dose-response studies have been conducted to establish the minimum and optimal requirements for the development of some specific tissues/organs [9-17], and suggesting that those requirements seem to be specific for different 
76

77

78

been carried out for deciphering the roles and requirements of different VA metabolites in fish immunocompetence [18-23]. Thus, the present study aimed at investigating the effects of different levels of dietary VA content on Senegalese sole immunocompetence against an induced bacterial infection. Furthermore, an expression analysis of representative immunerelated genes by relative quantitative PCR ( $\mathrm{PPCR}$ ) has been performed in order to gain some insights on how dietary VA content could affect Senegalese sole resistance to bacterial infection.

\section{Materials and methods}

\subsection{Ethics statement}

Present work was carried out in accordance with EU Directive 2010/63/EU for animal experiments (http://ec.europa.eu/environment/chemicals/lab animals/legislation en.htm), following approved protocols by the institutional ethics committee.

\subsection{Fish rearing and experimental diets}

Newly hatched larvae of Senegalese sole were obtained from Stolt Sea Farm SA (Cambre, La Coruña, Spain) and shipped to IRTA facilities. After their acclimatization, larvae were distributed in cylindrical tanks (100 L) connected to a recirculation unit (IRTAMarTM). Senegalese sole larvae were reared and fed enriched rotifers (Easy Selco ${ }^{\mathrm{TM}}$ ) first from 3 to 10 days post hatch (dph), after which from 6 dph onwards, larvae were fed with Artemia metanauplii containing increased levels of VA $(37,000,44,666,82,666$ and 203,000 total VA IU $\mathrm{kg}^{-1}$; labeled "Control", VA1, VA2 and VA3, respectively) by adding different amounts of retinyl palmitate $\left(1,600,000 \mathrm{IU} \mathrm{g}^{-1}\right.$, Sigma-Aldrich, Spain) to a commercial enrichment emulsion (Easy Selco $\left.{ }^{\mathrm{TM}}\right)$, as previously described [15]. From $33 \mathrm{dph}$ onwards early juveniles were fed with frozen Artemia metanauplii enriched according to the procedures mentioned above.

\subsection{Bacterial challenges}


103 Inoculum of Photobacterium damselae subsp. damselae (ATCC® 33539) (Phdd) was grown at

$10422{ }^{\circ}$ in tryptic soy broth (TSB) or tryptic soy aga r (TSA) supplemented with $\mathrm{NaCl}$ to a final

105 concentration of $2 \%(\mathrm{w} / \mathrm{v})$, then stored at $-80^{\circ} \mathrm{C}$ in TSB supplemented with $15 \%(\mathrm{v} / \mathrm{v})$ glycerol.

106 To prepare the inocula for intramuscular injection, frozen stock of bacteria were inoculated into

$10710 \mathrm{~mL}$ of TSB medium with $2 \% \mathrm{NaCl}$ and cultured for $24 \mathrm{~h}$ at $22{ }^{\circ} \mathrm{C}$ with continuous shaking

108 (90 rpm). Then, bacteria were inoculated onto TSA medium with $2 \% \mathrm{NaCl}$ overnight at the

109 same temperature. Colonies from exponentially growing bacteria were resuspended in sterile

110 sea water (SSW) with $2.5 \% \mathrm{NaCl}$ and the density of the culture was adjusted to McFarland

111 standard of 0.5 . From this suspension, 10 -fold dilutions ranging from $2^{*} 10^{1}$ to $2^{*} 10^{6} \mathrm{CFU} \mathrm{mL}^{-1}$

112 were prepared. Aliquots of the serial dilutions were plated onto TSA $2 \% \mathrm{NaCl}$ and the number

113 of CFU were counted following incubation at $22^{\circ} \mathrm{C}$ in order to confirm CFU concentrations. A

114 standard curve for this bacterium was developed by plotting optical density at $610 \mathrm{~nm}$ against

115 bacterial counts (CFU mL $\left.{ }^{-1}\right)$.

116 Three different challenge trials were performed in this study. In the first trial, the

117 determination of the $\mathrm{LD}_{50}$ for Phdd in Senegalese sole early juveniles $\left(\mathrm{LD}_{50}-\right.$ challenge) was

118 conducted in $45 \mathrm{dph}$ fish fed with 37,000 total VA IU kg-1 (Control group). Juveniles were

119 inoculated intramuscularly (10 fish per $1 \mathrm{~L}$ aquarium) with $10 \mu \mathrm{L}$ containing 0 (C), 6*10 $0^{1}, 6^{*} 10^{2}$,

$1206^{*} 10^{3}, 6^{\star} 10^{4}$ and $6^{*} 10^{5} \mathrm{CFU} \mathrm{\textrm {mL } ^ { - 1 }}$ suspended in SSW. Each dose was done in quadruplicate. A

121 second bacterial challenge trial was conducted to determine the resistance to an induced

122 bacterial infection of juveniles (60 dph; $15.4 \pm 1.2 \mathrm{~mm}$ in standard length) when fed with

123 increasing dietary VA levels (VA - challenge). Thus, fish from each dietary VA group $(n=7)$

124 were intramuscularly injected $(10 \mu \mathrm{L})$ with the $\mathrm{LD}_{50}$ previously calculated $\left(6^{*} 10^{2} \mathrm{CFU} \mathrm{mL}{ }^{-1}\right)$ in

125 quadruplicate. In addition, a Control group was also injected with $10 \mu \mathrm{L}$ of SSW (Control -

126 Control group). A third bacterial challenge trial was also implemented to get some insights on

127 how VA supplementation could modulate the immunocompetence of Senegalese sole juveniles

128 (75 dph). For this purpose 30 fish from the Control and VA3 groups were inoculated as

129 described in the $V A$ - challenge and 5 fish were sampled at 4, 8, 12 and $24 \mathrm{~h}$ post-injection 
130 (Underlying pathways - challenge). In all trials, fish were fed daily with frozen Artemia

131 previously enriched with their respective VA level, while water temperature was maintained at

$13218.0 \pm 1.0^{\circ} \mathrm{C}$ and with a $50 \%$ water renewal in aqua ria. Mortality was recorded on a daily

133 basis up to 18 days post injection. Survival rate (\%) was calculated as the final number of

134 inoculated fish / initial number of inoculated fish * 100 . All sampled fish were euthanized with

135 an overdose of anaesthetic (Tricaine methanesulfonate, MS-222, Sigma). Fish sampled during

136 the Underlying pathways - challenge were individually frozen in RNA later (Ambion®) and

137 stored at $-80{ }^{\circ} \mathrm{C}$ until gene expression analysis. Additionally, to confirm Phdd

138 presence/absence, several moribund Phdd infected fish, as well as healthy SSW injected

139 specimens were sampled, washed in SSW, directly frozen and stored at $-20 \stackrel{\circ}{\circ}$ until DNA

140 extraction.

142 2.3 DNA extraction and confirmation of presence of $P$. damselae subsp. damselae by PCR

143 Total DNA isolation from fish specimens (infected or not) was performed following a proteinase

$144 \mathrm{~K}$ lysis buffer protocol. Phdd presence/absence were then confirmed by PCR (initial

145 denaturation at $95{ }^{\circ} \mathrm{C}$ for $8 \mathrm{~min}$, followed by 40 cycles of a 1 min denaturation at $94{ }^{\circ} \mathrm{C}$,

146 annealing at $58^{\circ} \mathrm{C}$ for $1 \mathrm{~min}$, elongation at $72{ }^{\circ} \mathrm{C}$ for $1 \mathrm{~min}$ and a final extension of $10 \mathrm{~min}$ at 72

$147 \stackrel{\circ}{\circ}$ ) with 16S-like ssrDNA degenerate primers (Supplementary Table S1) and subsequent 148 sequencing of the resulting amplicon.

$150 \quad 2.4$ RNA extraction, reverse transcription and gene expression analysis

151 From 3 injected fish collected at each sampling time and from both dietary groups (Control and 152 VA3) total RNA was extracted using TRIzol reagent (Invitrogen®) following manufacturer 153 specifications. The quantity of RNA isolated was determined using a Gene-Quant 154 spectrophotometer (Amersham Biosciences), purity was established by the absorbance ratio $155260 / 280 \mathrm{~nm}$ (ranging from 1.7 to 2.0 in all samples). The quality of the RNA was examined 156 using 1.2\% TAE agarose gel electrophoresis. A reverse transcription reaction was carried out 
157 using equal quantities of total RNA $(1 \mu \mathrm{g})$ from each sample and Quanti Tect Reverse

158 Transcription Kit (Qiagen $\AA$ ). Electrophoresis using a 1.2\% TAE agarose gel was run to assess

159 the RT-PCR product. Real-time qPCR was performed using an ABI PRISM 7300 (Applied

160 Biosystems). For each gene, species and gene-specific primers were designed according to

161 sequences available in GenBank (NCBI, www.ncbi.nlm.nih.gov) and the SoleaDB databases

162 (www.aquagenet.eu; Supplementary Table S1). The efficiencies of all qPCR reactions were 163 close to $100 \%$. qPCR reactions were performed in triplicate in 96-well plates containing: $10 \mu \mathrm{L}$ 164 of SYBR® Green PCR Master Mix (Life Technologies), $0.5 \mu \mathrm{L}$ of forward and reverse primers $165(10 \mu \mathrm{M}), 7 \mu \mathrm{L}$ of molecular biology grade water (Sigma), and $2 \mu \mathrm{L}$ of a 1:10 dilution of cDNA 166 template. Standard amplification parameters were: $95 \stackrel{\circ}{\circ}$ for 5 min followed by 45 amplification 167 cycles ( $95{ }^{\circ} \mathrm{C}$ for $45 \mathrm{~s}, 59 \stackrel{\circ}{\mathrm{C}}$ for $1 \mathrm{~min}$ and $70 \stackrel{\circ}{\mathrm{C}}$ for $1 \mathrm{~min}$ ). A final dissociation reaction (melting 168 curve) was performed ( $95{ }^{\circ} \mathrm{C}$ for $15 \mathrm{~s}, 60{ }^{\circ} \mathrm{C}$ for $20 \mathrm{~s}, 95{ }^{\circ} \mathrm{C}$ for $15 \mathrm{~s}$ and $60{ }^{\circ} \mathrm{C}$ for $15 \mathrm{~s}$ ) to 169 evaluate the specificity of the amplicons. A calibrator sample was included in each qPCR plate $170 \quad[24]$.

\section{$172 \quad 2.5$ Data Processing}

173 Relative gene expression was determined from the ratio between PCR efficiency and threshold cycle of a sample compared with the control, and expressed in comparison to the reference gene, according to Pfaffl's mathematical model [25]. Relative gene expression was normalized

176 using ubiquitin (Ubq), a previously reported reference gene for accurate normalization in qPCR 177 studies with Senegalese sole [26], and using the gene expression level of the Control group as 178 reference sample.

$180 \quad 2.6$ Statistical analysis

181 Results are given as mean \pm standard deviation. All data were checked for normality 182 (Kolmogorov-Smirnov test) and homoscedasticity of variance (Bartlett's test). Survival rate 
expressed in percentage was arcsin square root transformed before statistical analyses.

184 Significant differences in survival rate and in gene expression ratios during the time course of

185 infection (0-24 h post injection) in fish fed with Control diet were detected by one-way ANOVA,

186 and by T-test at each sampling time between the Control and VA3 dietary groups. When

187 differences were significant by the ANOVA test, the Tukey multiple-comparison test was used

188 to detect differences among experimental groups. Differences were considered to be significant

189 when $P<0.05$. The correlation between fish mortality and total VA levels in enriched Artemia

190 metanauplius was evaluated by means of the Pearson Product Moment Correlation test. All

191 statistical analyses were conducted using SigmaStat 3.0 (Systat Software Inc.).

\section{3. Results and discussion}

194 Although Phdd is a moderately virulent pathogen, it is one of the most common pathogens associated with newly cultured fish species $[4,27]$. In the present study, we found a $L_{50}$ of 6 CFU per fish in Senegalese sole early juveniles (around 10-20 mg dry weight; Supplementary

197 Figure S1) and therefore, this bacterial load was applied subsequently to decipher whether

198 dietary VA level improved Senegalese sole early juvenile's immunocompetence.

3.1 Dietary VA supplementation improve the resistance of Senegalese sole early juveniles to an induced bacterial infection

202 The intensive culture of fish species has favored the occurrence of several outbreaks with

203 Photobacterium damselae subsp. damselae resulting in moderate mortality [30]. Despite 204 increasing knowledge about Phdp pathogenesis, relatively little is yet known about how Phdd 205 induces fish mortality (reviewed in Labella et al. [4]). Further, the effectiveness of 206 chemotherapy treatments remains limited [28, 29] when confronted with isolates of Phdp and

207 Phdd possessing multidrug resistance genes which can be transferred horizontally. Therefore, 208 immunoprophylaxis seems to be the best way to prevent pasteurellosis. Autovaccines against 209 Phdp have been used in some farms [1], but their efficacy is dependent on the fish species, 
210 fish size, vaccine formulation and immunostimulants used [30]. In addition, recent studies on

211 probiotics to control Photobacteriosis have given encouraging results [31, 32]. Under current

212 experimental conditions, Senegalese sole early juveniles fed with a VA-supplemented diet

$213\left(203,000\right.$ total VA IU $\left.\mathrm{Kg}^{-1}\right)$ showed a higher resistance to an induced bacterial infection with

214 Phdd (Fig. 1; ANOVA, $P<0.05$ ), with approximately a 50\% reduction in endpoint mortality in

215 comparison to the Control group $\left(37,000\right.$ total VA IU Kg${ }^{-1} ; 36.6 \pm 11.8$ and $89.3 \pm 13.7 \%$ of

216 cumulative mortality, respectively); and a statistically significant negative correlation between

217 endpoint mortality rates and total VA dietary content $(\mathrm{R}=-0.971 ; P=0.02$; Pearson Product

218 Moment Correlation test). This confirmed that VA has a role in Senegalese sole

219 immunocompetence. Similar results were found regarding the enhancement of the immnune

220 system by retinoids in freshwater [18-20] and marine fish species [21-23]. In order to confirm

221 that fish mortality was caused by the intramuscular injection of $P h d d$, moribund challenged fish

222 and healthy control ones injected with SSW were sampled. Confirmation of presence/absence

223 of Phdd was done by PCR (Supplementary Figure S2).

3.2 VA might ameliorate the response to Phdd infection through different immune pathways

226 Phdd induced pathogenicity and mortality are known to be caused by excreted cellular protein

227 components such as proteases, hemolysins, and siderophore-mediated iron sequestering

228 proteins (reviewed in Labella et al. [4]). However, how the fish immnune system responds to 229 this pathogen is still unknown. Thus, the time course response to Phdd infection in sole 230 juveniles fed the Control and the highest VA supplemented (VA3) diets was evaluated by 231 analyzing the expression of genes from the immune system.

232 All evaluated genes showed no differences in their expression levels between fish fed the

233 Control and VA3 diets before the bacterial challenges (Figs. 2 and 3; T-test, $P>0.05$ ),

234 indicating that VA might prime the system to give an enhanced response upon stimulation by 235 pathogen infection [33]. It is known that VA metabolites improve the immunocompetence in 236 vertebrates [33]. Fish fed with synthetic or natural $\beta$-carotene and astaxanthin supplemented 
237 diets had a higher serum complement activity, lysozyme activity, phagocytic activity and better

238 non-specific cytotoxicity in peripheral blood lymphocytes, increasing the bio-defense

239 mechanisms of the organism [18-20]. Furthermore, fish fed diets supplemented with

240 astaxanthin showed higher resistance against infectious hematopoietic necrosis virus (IHNV)

241 [20], while fish fed with high levels of retinol acetate, respiratory burst activity, leukocyte

242 cytotoxic activity and total serum immunoglobulin M were enhanced [21-23].

243 Although additional analyses are required, the present work showed some potential

244 underlying pathways by which VA might ameliorate fish immunocompetence. At $24 \mathrm{~h}$ post

245 infection (hpi) a higher gene expression (ANOVA, $P<0.05$ ) of the three main molecular players

246 of the complement system was observed (Figure 2): complement component 1 inhibitor (C1inh;

247 from the classical and lectin pathway), complement component 3 (C3; from the alternative

248 pathway) and complement component 9 (C9; from the cytolytic pathway). Those findings were

249 in partial agreement with those reported in Senegalese sole [34] and other fish species [35]

250 after an infection with Phdp, where it was proposed that activation of complement provided protection against $P h d p$ infection [35]. The common response among fish species (activation of complement) against multiple pathogens suggests that the supplementation of diet with VA can

253 be used as an immunoprophylactic measure in different fish species and against more than 254 one pathogen.

255 A higher expression of C1inh was observed in fish fed with supplemented VA diets at 8 and 12 hpi compared with that of infected soles fed with the Control diet (Fig. 2; T-test, $P<0.05$ ). Interestingly, the classical and lectin pathway mainly relies on the activation of the $\mathrm{C} 1$ complex, which is under control of the $\mathrm{C} 1$-inhibitor that forms a proteolytically inactive stoichiometric

259 complex with the $\mathrm{C} 1 \mathrm{r}$ or $\mathrm{C} 1 \mathrm{~s}$ proteases. Although activation of the $\mathrm{C} 1$ complex plays crucial 260 roles for successful host defense, excessive activation of complement can potentially cause 261 serious damage to the host, leading to anaphylaxis and cell damage [36]. Similarly, a higher 262 gene expression of $C 3$ in Senegalese sole fed VA3 diet was also reported, although it was only 263 significant at $12 \mathrm{hpi}$ (Fig. 2; T-test, $P<0.05$ ). Complement C3 is the central protein of all three 
264 activation pathways and essential in alerting the host of the presence of potential pathogens, 265 contributing significantly to the orchestration and development of an acquired immune 266 response [36, 37]. The highest gene expression of C3 in Senegalese sole was found in the

267 group fed with Control diet at $24 \mathrm{hpi}$, which is in accordance with results reported in different 268 fish species after $24 \mathrm{~h}$ infection with Phdp [38]. In contrast, C9 up-regulation in infected fish started at $4 \mathrm{hpi}$, but was only seen to be significantly different at $24 \mathrm{hpi}$ in VA3 group. The ninth component of the complement is a single-chain glycoprotein that is involved in the formation of the membrane attack complex (MAC) on the surface of target cells [38].

The current study also provides new insights on other potential underlying pathways by which dietary VA content can improve fish immunocompetence. In this sense, expression of 274 lysozyme $C($ LysC), lectin galactoside-binding soluble 1 (galectin 1)-like 3 (Lgals1), peroxiredoxin-1 (Prdx1, also known as natural killer cell-enhancing factor), hepcidin (Hamp), transferrin (Transf), and metalloreductase six-transmembrane epithelial antigen of prostate 4 (Steap4; also known as tumor necrosis factor, alpha-induced protein 9) were also evaluated. Lysozymes exhibit antimicrobial properties by hydrolysis of $\mathrm{N}$-acetylmuramic acid and $\mathrm{N}$ acetylglucosamine, which are constituents of the peptidoglycan layer of bacterial cell walls [39].

280 Our results showed that from the initiation of infection onwards, $L y s C$ was significantly downregulated in both experimental groups (Control and VA3; Fig. 3; ANOVA, $P<0.05$ ) and no significant differences at any post injection times were observed between them regarding the effect of dietary VA level (T-test, $P>0.05)$. This is in contrast with previous reports regarding LysC in Senegalese sole after infection with Phdp [34, 40].

Similarly to gene expression results found for $L y s C$, Prdx1 did not differ between

286 Senegalese soles fed Control and VA3 diets after the Phdd infection (Fig. 3; T-test, $P>0.05$ ),

287 being significantly down-regulated at all sampling points after infection (ANOVA, $P<0.05$ ).

288 Prdx enzymes efficiently reduce the increase in the intracellular concentration of $\mathrm{H}_{2} \mathrm{O}_{2}$, 289 suggesting an important function in signaling cascades by removing $\mathrm{H}_{2} \mathrm{O}_{2}$ [41] and in the 290 immunoregulation of the activity of natural killer cells (NK) [42]. Since NK cells are involved in 
291 the recognition and destruction of host cells infected with pathogens, two hypotheses may be

292 proposed. The first one is in relation to the lower infection suffered by VA3 fed fish due to the

293 limited availability of iron for bacterial growth (see comments below), whereas the second

294 hypothesis is that it could represent one mechanism of evasion of the immune response by

295 Phdd due to the action of some proteases [43]. In contrast to Prdx1 gene expression, we

296 reported an increased gene expression of Lgals 1 in Senegalese sole early juveniles challenged

297 with Phdd after 4 hpi (Fig. 3; ANOVA, $P<0.05$ ), regardless of the dietary VA content. Lectins

298 are proteins that bind to specific carbohydrate moieties on cell surfaces, assisting in the rapid

299 clearance of pathogens by enhancing opsonization and phagocytosis [44]. Thus, present

300 results were in agreement with their proposed function, the removal of pathogens after the

301 onset of infection as previously found in infected fish [45].

302 Finally, we analyzed the expression of genes involved in the regulation of iron homeostasis

303 since one of the main virulence factors of $P h d d$ is its high-affinity siderophore-mediated iron-

304 sequestering system [4]. The ability to acquire iron by pathogenic bacteria is essential for the

305 growth and ability to cause infections within the host. Hepcidin (Hamp) is a small cysteine-rich

306 protein with antimicrobial activity and an important role in iron homeostasis. Increased gene

307 expression of Hamp in Phdd-challenged Senegalese sole early juveniles from 8 hpi onwards

308 was found in this study (Fig. 3; ANOVA, $P<0.05$ ). Similar results were observed in

309 Senegalese sole exposed to LPS [46]. This gene expression pattern was observed regardless

310 of the dietary VA content, with the exception of the 8 hpi sampling point, when fish fed with VA

311 supplemented diets had a significantly lower gene expression of Hamp than those fed the

312 Control diet (T-test, $P<0.05)$. However and in contrast to Hamp gene expression, transferrin

313 (Transf) gene expression was significantly up-regulated only at $24 \mathrm{hpi}$ in Senegalese sole fed

314 with Control diet (ANOVA, $P<0.05)$, whereas fish fed the VA3 diet already exhibited a higher

315 gene expression value compared to the Control fish at 4 hpi. This higher level of expression

316 was maintained until $24 \mathrm{hpi}$ (Fig. 3; T-test, $P<0.05$ ). This increase in gene expression was in

317 accordance with the presence of a VA response element in the promoter of transferrin [47]. 
318 Since tranferrin is a protein with a high affinity for iron, lowering the availability of iron in

319 vertebrate tissues, VA might inhibit bacterial growth indirectly in this way [48], and thereby

320 increase the survival of fish fed with the VA3 diet. In addition, the gene expression of Steap4

321 (also known as tumor necrosis factor, alpha-induced protein 9) was also up-regulated in fish

322 from the Control group infected with Phdd from 12 hpi onwards (Fig. 3; ANOVA, $P<0.05$ );

323 which was in agreement with its up-regulation in sole exposed to LPS [46]. In contrast, there

324 was a significant reduction of Steap4 expression at each sampling point in infected fish from

325 the VA3 group (T-test, $P<0.05$ ). Although Steap4 is capable of facilitating the cellular uptake

326 of iron [49] it is induced by TNF- $\alpha$ as a protective anti-inflammatory factor [50] and it has been

327 reported to be down-regulated by all-trans RA (the main active VA metabolite), thereby

328 redirecting the immune balance towards immunoglobulin production and a humoral immune

329 response [51]. This was in accordance with present results regarding a reduced expression of

330 Steap4 in soles fed with the VA3 diet from 4 hpi onwards (T-test, $P<0.05$ ), concomitantly with

331 the reported higher RA levels in VA3 diet fed soles than in those fed Control diet [15].

332

\section{4. Conclusions}

335 Sole fed higher doses of dietary VA were more resistant against a bacterial challenge with

336 Phdd. The lower mortality rate in fish fed higher VA dietary content (203,000 total VA IU Kg $\left.{ }^{-1}\right)$

337 was probably due to the stimulation by RA of the immune response system, and particularly by

338 (i) avoiding cell damage and anaphylaxis by the excessive activation of the C1 complex

339 through the control of $\mathrm{C} 1$ inhibitor, and (ii) reducing iron availability for growth and concomitant

340 pathogenity of Phdd mainly through transferrin and Steap4 regulation. Furthermore, this work

341 highlights the need for integrative research on fish nutritional requirements, since the same

342 dietary VA content that hampered skeletal development [15] stimulated fish

343 immunocompetence (present study). Such opposed effects in both systems might be due to an

344 osteoimmunology cross-talk that remains to be uncovered in fish species. Finally, feeding 
345 metamorphosed Senegalese sole with 203,000 total VA IU $\mathrm{Kg}^{-1}$ might be an effective,

346 inexpensive and environmental-friendly method to improve Senegalese sole

347 immunocompetence while avoiding the inducement of skeletal deformities.

349 Acknowledgements

350 This work was funded by grant AGL2005-02478 from the Ministry of Education and Culture

351 (MEC) of the Spanish Government. IF was supported by a predoctoral Spanish fellowship 352 (BES-2006-12650) and a Portuguese postdoctoral fellowship (SFRH/BPD/82049/2011) and

353 CL-J was supported by a predoctoral Spanish fellowships (INIA RTA 2005-00079-00-00 and 354 RTA 421 2007-00063-00-00) and a French postdoctoral fellowship (DRH/LG/JC № 2013-865).

\section{References}

[1] Morais S, Aragão C, Cabrita E, Conceição LEC, Constenla M, Costas B, Dias J, Duncan N,

358 Engrola S, Estévez A, Gisbert E, Mañanos E, Valente LMP, Yufera M, Dinis MT. New developments and biological insights into the farming of Solea senegalensis reinforcing its aquaculture potential. Rev Aquaculture 2014; 6:1-37.

[2] Martins P, Cleary DFR, Pires ACC, Rodrigues AM, Quintino V, Calado R, Gomes NCM. Molecular analysis of bacterial communities and detection of potential pathogens in a recirculating aquaculture system for Scophthalmus maximus and Solea senegalensis. Plos One 2013; 8:1.

[3] Romalde JL. Photobacterium damselae subsp. piscicida an integrated view of a bacterial fish pathogen. Int Microbiol 2002; 5:3-9.

[4] Labella A, Berbel C, Manchado M, Castro D, Borrego JJ. Photobacterium damselae subsp. damselae, an emerging pathogen affecting new cultured marine fish species in Southern Croatia. 
371 [5] Kiron V. Fish immune system and its nutritional modulation for preventive health care.

$372 \quad$ Animal Feed Science and Technology 2012; 173:111-33.

373 [6] Oliva-Teles A. Nutrition and health of aquaculture fish. J Fish Dis 2012; 35:83-108.

374 [7] Ross SA, Caffery PJ, Draguer UC, De Luca LM. Retinoids in embryonal development. 375 Physiol Rev 2000; 80:1021-54.

376 [8] Manicassamy S, Pulendran B. Retinoic acid-dependent regulation of immune responses by 377 dendritic cells and macrophages. Semin Immunol 2009; 21:22-7.

378 [9] Fernández I, Gisbert E. The effect of vitamin A on flatfish development and skeletogenesis: 379 a review. Aquaculture 2011; 315:34-48.

380 [10] Haga Y, Du S, Satoh S, Kotani T, Fushimi H, Takeuchi Y. Analysis of the mechanism of 381 skeletal deformity in fish larvae using a vitamin A-induced bone deformity model. $382 \quad$ Aquaculture 2011; 315:26-33.

383 [11] Mazurais D, Darias M, Fernández I, Cahu C, Gisbert E, Zambonino-Infante JL. Gene

393 [14] Fernández I, Tiago DM, Laizé V, Cancela LM, Gisbert E. Retinoic acid differentially affects 394 in vitro proliferation, differentiation and mineralization of two fish bone-derived cell lines: 395 different gene expression of nuclear receptors and ECM proteins. J Steroid Biochem Mol $396 \quad$ Biol 2014; 140:34-43. 
397 [15] Fernández I, Pimentel MS, Ortiz-Delgado JB, Hontoria F, Sarasquete C, Estévez A, 398 Zambonino-Infante JL, Gisbert E. Effect of dietary vitamin A on Senegalese sole (Solea 399 senegalensis) skeletogenesis and larval quality. Aquaculture 2009; 295:250-65.

400 [16] Fernández I, Gisbert E. Senegalese sole bone tissue originated from chondral ossification 401 is more sensitive than dermal bone to high vitamin A content in enriched Artemia. J $402 \quad$ Appl Ichthyol 2010; 26:344-49.

403 [17] Marques CL, Fernández I, Rosa J, Viegas MN, Cancela ML, Laizé V. Spatiotemporal 404 expression and retinoic acid regulation of bone morphogenetic proteins 2, 4 and 16 in $405 \quad$ Senegalese sole. J Appl Ichthyol 2014; 30:713-20.

406 [18] Amar EC, Kiron V, Satoh S, Watanabe T. Influence of various dietary synthetic carotenoids 407 on bio-defence mechanisms in rainbow trout, Oncorhynchus mykiss (Walbaum). Fish $408 \quad$ Shellfish Immunol 2001; 32:162-73.

409 [19] Amar EC, Kiron V, Satoh S, Watanabe T. Enhancement of innate immunity in rainbow 410 trout (Oncorhynchus mykiss Walbaum) associated with dietary intake of carotenoids from 411 natural products. Fish Shellfish Immunol 2004; 16:527-37.

412 [20] Amar EC,Viswanath K, Tetsuya A, Satoh S, Watanabe T. Resistance of rainbow trout 413 Oncorhynchus mykiss to infectious hematopoietic necrosis virus (IHNV) experimental 414 infection following ingestion of natural and synthetic carotenoids. Aquaculture 2012; $415 \quad 330: 148-55$.

416 [21] Cuesta A, Ortuño J, Rodriguez A, Esteban MA, Meseguer J. Changes in some innate 417 defence parameters of seabream (Sparus aurata L.) induced by retinol acetate. Fish 418 Shellfish Immunol 2002; 13:279-91.

419 [22] Cuesta A, Esteban MA, J. Meseguer J. Tumoricidal activity of gilthead seabream (Sparus 420 aurata L.) natural cytotoxic cells: the role played in vitro and in vivo by retinol acetate. Fish $421 \quad$ Shellfish Immunol 2003; 14:133-44. 
422 [23] Cuesta A, Meseguer J, Esteban MA. Total serum immunoglobulin M levels are affected by 423 immunomodulators in seabream (Sparus aurata L.). Vet Immunol Immunop 2004; 101 :203$424 \quad 10$.

425 [24] Derveaux S, Jo Vandesompele J, Hellemans J. How to do successful gene expression 426 analysis using real-time PCR. Methods 2010; 50:227-30.

427 [25] Pfaffl MW, Tichopad A, Prgomet C, Neuvians TP. Determination of stable housekeeping 428 genes, differentially regulated target genes and sample integrity: Bestkeeper-Excell-based 429 tool using pairwise correlations. Biotechnol Lett 2004; 26:509-15.

430 [26] Infante C, Matsuoka MP, Asensio E, Cañavate JP, Reith M, Manchado M. Selection of 431 housekeeping genes for gene expression studies in larvae from flatfish using real-time PCR. $432 \quad$ BMC Mol Biol 2008; 9:28.

433 [27] Labella A, Manchado M, Alonso MC, Castro D, Romalde JL, Borrego JJ. Molecular 434 intraspecific characterization of Photobacterium damselae ssp damselae strains affecting $435 \quad$ cultured marine fish. J Appl Microbiol 2010; 108: 2122-32.

436 [28] Kim MJ, Hirono I, Kurokawa K, Maki T, Hawke J, Kondo H, Santos MD, Aoki T. Complete DNA sequence and analysis of the transferable multiple-drug resistance plasmids ( $R$ Plasmids) from Photobacterium damselae subsp. piscicida isolates collected in Japan and the United States. Antimicrob Agents Chemother 2008; 52:606-11.

[29] Nonaka L, Maruyama F, Miyamoto M, Miyakoshi M, Kurokawa K, Masuda M. Novel conjugative transferable multiple drug resistance plasmid pAQU1 from Photobacterium damselae subsp. damselae isolated from marine aquaculture environment. Microbes Environ 2012; 27:263-72.

[30] Arijo S, Rico R, Chabrillon M, Diaz-Rosales P, Martínez-Manzanares E, Balelona MC, Magariños B, Toranzo AE, Moriñigo MA. Effectiveness of a divalent vaccine for sole, Solea senegalensis (Kaup), against Vibrio harveyi and Photobacterium damselae subsp. piscicida. J Fish Dis 2005; 28:33-8. 
448 [31] Garcia de la Banda I, Lobo C, Chabrillo M, Leon-Rubio JM, Arijo S, Pazos G, Lucas LM,

449 Moriñigo MA. Influence of dietary administration of a probiotic strain Shewanella

450 putrefaciens on Senegalese sole (Solea senegalensis, Kaup 1858) growth, body

451 composition and resistance to Photobacterium damselae subsp piscicida. Aquac Res 2012;

$452 \quad 43: 662-9$.

453 [32] Batista S, Tapia-Paniagua ST, Moriñigo MA, Nunez-Diaz JA, Goncalves JFM, Barros R,

454 Cristovao B, Valente LMP, Ozorio ROA. Expression of immune response genes in sole

455 (Solea senegalensis, Kaup 1858) induced by dietary probiotic supplementation following

456 exposure to Photobacterium damselae subsp. piscicida. Fish Shellfish Immunol 2013;

$457 \quad 34: 1638-39$.

458 [33] Mora JR, Iwata M, von Andrian UH. Vitamin effects on the immune system: vitamins A and

459 D take centre stage. Nat Rev 2008; 8:685-98.

460 [34] Costas B, Régo PCNP, Simões I, Marques JF, Castro-Cunha M, Afonso A. Cellular and 461 humoral immune responses of Senegalese sole (Solea senegalensis Kaup, 1858) following challenge with two Photobacterium damselae subsp. piscicida strains from different geographical origins. J Fish Dis 2013; 36:543-53.

464 [35] Acosta F, Ellis AE, Vivas J, Padilla D, Acosta B, Deniz S, Bravo J, Real F. Complement 465 consumption by Photobacterium damselae subsp. piscicida in seabream, red porgy and 466 seabass normal and immune serum. Effect of the capsule on the bactericidal effect. Fish 467 Shellfish Immunol 2006; 20:709-17.

468 [36] Nakao M, Tsujikura M, Ichiki S, Vo TK, Somamoto T. The complement system in teleost 469 fish: progress of post-homolog-hunting researches. Dev Comp Immunol 2011; 35:1296-308.

470 [37] Boshra H, Li J, Sunyer JO. Recent advances on the complement system of teleost fish. $471 \quad$ Fish Shellfish Immunol 2006; 20:239-62.

472 [38] Mauri I, Romero A, Acerete L, Mackenzie S, Roher N, Callol A, Cano I, Alvarez MC, Tort L. 473 Changes in complement responses in Gilthead seabream (Sparus aurata) and European 
474 seabass (Dicentrarchus labrax) under crowding stress, plus viral and bacterial challenges.

$475 \quad$ Fish Shellfish Immunol 2011; 30:182-88.

476 [39] Jollès $P$, Jollès J. What's new in lysozyme research? Always a model system, today as $477 \quad$ yesterday. Mol Cell Biochem 1984; 63:165-89.

478 [40] Fernández-Trujillo MA, Porta J, Manchado M, Borrego JJ, Alvarez MC, Bejar J. c479 Lysozyme from Senegalese sole (Solea senegalensis): cDNA cloning and expression $480 \quad$ pattern. Fish Shellfish Immunol 2008; 25:697-700.

481 [41] Chang TS, Jeong W, Choi SY, Yu SQ, Kang SW, Rhee SG. Regulation of perosiredoxin I 482 activity by Cdc2-mediated phosphorylation. J Biol Chem 2002; 277:25370-376.

483 [42] Shau HG, Buttlerfield LH, Chiu R, Kim A. Cloning and sequence-analysis of candidate 484 human natural killer enhancing factor genes. Immunogenetics 1994; 40:129-34.

485 [43] Vivas J, Razquin BE, Lopez-Fierro P, Naharro G, Villena A. Correlation between 486 production of acyl homoserine lactones and proteases in an Aeromonas hydrophila aroA live $487 \quad$ vaccine. Vet Microbiol 2004; 101:167-76.

488 [44] Dutta S, Bhattacharya B, Chatterjee B, Mazumder S. Characterization of a galactose 489 binding serum lectin from the Indian catfish, Clarias batrachus: Possible involvement of fish 490 lectins in differential recognition of pathogens. Comp Biochem Physiol C 2005; 141:76-84.

491 [45] Pellizzari C, Krasnov A, Afanasyev S, Vitulo N, Franch R, Pegolo S, Patarnello T, 492 Bargelloni L. High mortality of juvenile gilthead sea bream (Sparus aurata) from 493 photobacteriosis is associated with alternative macrophage activation and anti-inflammatory 494 response: Results of gene expression profiling of early responses in the head kidney. Fish 495 Shellfish Immunol 2013; 34:1269-1278.

496 [46] Osuna-Jiménez I, Williams TD, Prieto-Alamo MJ, Abril N, Chipman JK, Pueyo C. Immune497 and stress-related transcriptomic responses of Solea senegalensis stimulated with 498 lipopolysaccharide and copper sulphate using heterologous cDNA microarrays. Fish 499 Shellfish Immunol 2009; 26:699-706. 
500 [47] Hsu SL, Lin YF, Chou CK. Transcriptional regulation of transferrin and albumin genes by

$501 \quad$ retinoic acid in human hepatoma cell line Hep3B. Biochem J 1992; 283:611-5.

502 [48] Ellis AE. Immunity to bacteria in fish. Fish Shellfish Immunol 1999; 9:291-08.

503 [49] Ohgami RS, Campagna DR, McDonald A, Fleming MD. The Steap proteins are 504 metalloreductases. Blood 2006; 108: 1388-94.

505 [50] Moldes M, Lasnier F, Gauthereau X, Klein C, Pairault J, Feve B, Chambaut-Guerin AM. 506 Tumor necrosis facor-alpha-induced adipose-related protein (TIARP), a cell-surface protein 507 that is highly induced by tumor necrosis factor-alpha and adipose conversion. J Biol Chem $508 \quad 206 ; 33938-33946$.

509 [51] Wang X, Allen C, Ballow M. Retinoic acid enhances the production of IL-10 while reducing 510 the synthesis of IL-12 and TNF-alpha from LPS-stimulated monocytes/macrophages. J Clin $511 \quad$ Immunol 2007; 27:193-00.

512

513

514

515

516

517

518

519

520

521

522

523

524

525

526 


\section{$530 \quad$ Figure captions}

532 Figure 1. Fish mortality (\%) during 18 days post injection of Photobacterium damselae subsp. damselae strain 33539 in Senegalese sole (Solea senegalensis) early juveniles fed with

534 Artemia metanauplii containing increased levels of vitamin A (VA). Fish were fed with Artemia 535 enriched with $37,000,44,666,82,666$ and 203,000 total VA IU $\mathrm{Kg}^{-1}$ and infected by 536 intramuscular injection of $10 \mu \mathrm{L}$ of $P$. damselae subsp. damselae suspension $\left(6^{\star} 10^{2} \mathrm{CFU} \mathrm{mL}^{-1}\right.$ 537 in SSW; Inf-C, Inf-VA1, Inf-VA2 and Inf-VA3, respectively); or fed with Artemia enriched with 53837,000 total VA IU Kg ${ }^{-1}$ and injected intramuscularly with $10 \mu \mathrm{L}$ of SSW (Control). Different 539 letters at each day post injection denote significant differences in mortality among the different 540 dietary regimes (ANOVA; $P<0.05)$. Each experimental group was done in quadruplicate $(n=$ $5417)$.

543 Figure 2. Time course of relative gene expression of some molecular players of the 544 complement pathway in Senegalese sole (Solea senegalensis) early juveniles after injection 545 with Photobacterium damselae subsp. damselae strain 33539. Relative gene expression was 546 from fish fed with Artemia enriched with 37,000 (black bars; Control) or 203,000 total VA IU Kg

$547{ }^{1}$ (white bars; VA3) before (0 hours post injection; hpi) and 4, 8, 12 and 24 hpi intramuscularly 548 of $10 \mu \mathrm{L}$ of suspension of $P$. damselae subsp. damselae strain $33539\left(6^{\star} 10^{2} \mathrm{CFU} \mathrm{mL} \mathrm{m}^{-1} \mathrm{SSW}\right)$.

549 Different letters denote significant differences between sampling points of Control group 550 (ANOVA, $P<0.05$ ). Asterisk denotes significant differences between Control and VA3 groups 551 at each sampling point (T-test, $P<0.05)$. Bars represent the relative gene expression mean 552 values of three individuals from each experimental group (biological replicates; $n=3$ ). Relative 553 gene expression of each biological replicate was run in triplicate (technical replicates; $n=3$ ). 
554 Control fish at $0 \mathrm{hpi}$ was the reference sample for relative gene expression analysis and set to

555 1. The housekeeping gene used was ubiquitin (Ubq). C1inh, C1 esterase inhibitor; C3,

556 Complement component C3; C9, Complement component C9.

557

558 Figure 3. Time course of relative gene expression of some other molecular players involved in

559 the immune system of Senegalese sole (Solea senegalensis) early juveniles after injection with

560 Photobacterium damselae subsp. damselae strain 33539. Relative gene expression was from

561 fish fed with Artemia enriched with 37,000 (black bars; Control) or 203,000 total VA IU Kg ${ }^{-1}$

562 (white bars; VA3) before (0 hours post injection; hpi) and 4, 8, 12 and 24 hpi intramuscularly of

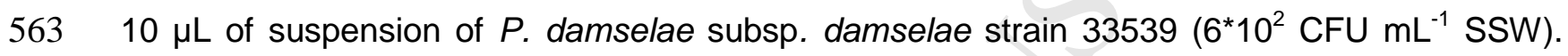

564 Different letters denote significant differences between sampling points of Control group 565 (ANOVA, $P<0.05$ ). Asterisk denotes significant differences between Control and VA3 groups 566 at each sampling point (T-test, $P<0.05)$. Bars represent the relative gene expression mean 567 values of three individuals from each experimental group (biological replicates; $n=3$ ). Relative 568 gene expression of each biological replicate was run in triplicate (technical replicates; $n=3$ ).

569 Control fish at 0 hpi was the reference sample for relative gene expression analysis and set to 570 1. The housekeeping gene used was ubiquitin (Ubq). Hamp, Hepcidin; Steap4, 571 Metalloreductase six-transmembrane epithelial antigen of prostate 4; $\operatorname{Prdx1}$, Peroxiredoxin-1;

572 LysC, Lysozyme C; Transf, Transferrin; Lgals 1, Lectin, galactoside-binding, soluble, 1 (galectin 573 1)-like 3.

574

575 Supplementary Figure S1. Cumulative fish mortality (\%) induced with intramuscular injection

$576(10 \mu \mathrm{L})$ of different suspensions of $P$. damselae subsp. damselae strain 33539 ranging from 0 577 (Control) to $6{ }^{*} 10^{5} \mathrm{CFU} \mathrm{mL}{ }^{-1} \mathrm{SSW}$ (in quatriplicates) in Senegalese sole (Solea senegalensis) 578 early juveniles $(n=10)$ for lethal dose $50\left(\mathrm{LD}_{50}\right)$ determination. 
580 Supplementary Figure S2. Agarose gel showing PCR products amplified with 16S-like

581 ssrDNA degenerate primers from pure culture of Photobacterium damselae subsp. damselae

582 strain 33539 (B), SSW injected (C), and 4 moribund infected Senegalese sole (Solea

583 senegalensis) early juveniles (1, 2, 3 and 4). L, $1 \mathrm{~Kb}$ Plus DNA Ladder Invitrogen®. Note the

584 corresponding amplicon of $1,424 \mathrm{bp}$ from the $16 \mathrm{~S}$ gene of Phdd from the pure culture, the

585 absence of an amplicon from euthanized fish injected with SSW, and the same band in 4

586 different moribund infected juveniles. Amplicons from pure bacterial culture and infected fish

587 were sequenced, analyzed using BLAST in GenBank at NCBI and identified as $P$. damselae 588 subsp. damselae strain 33539. 


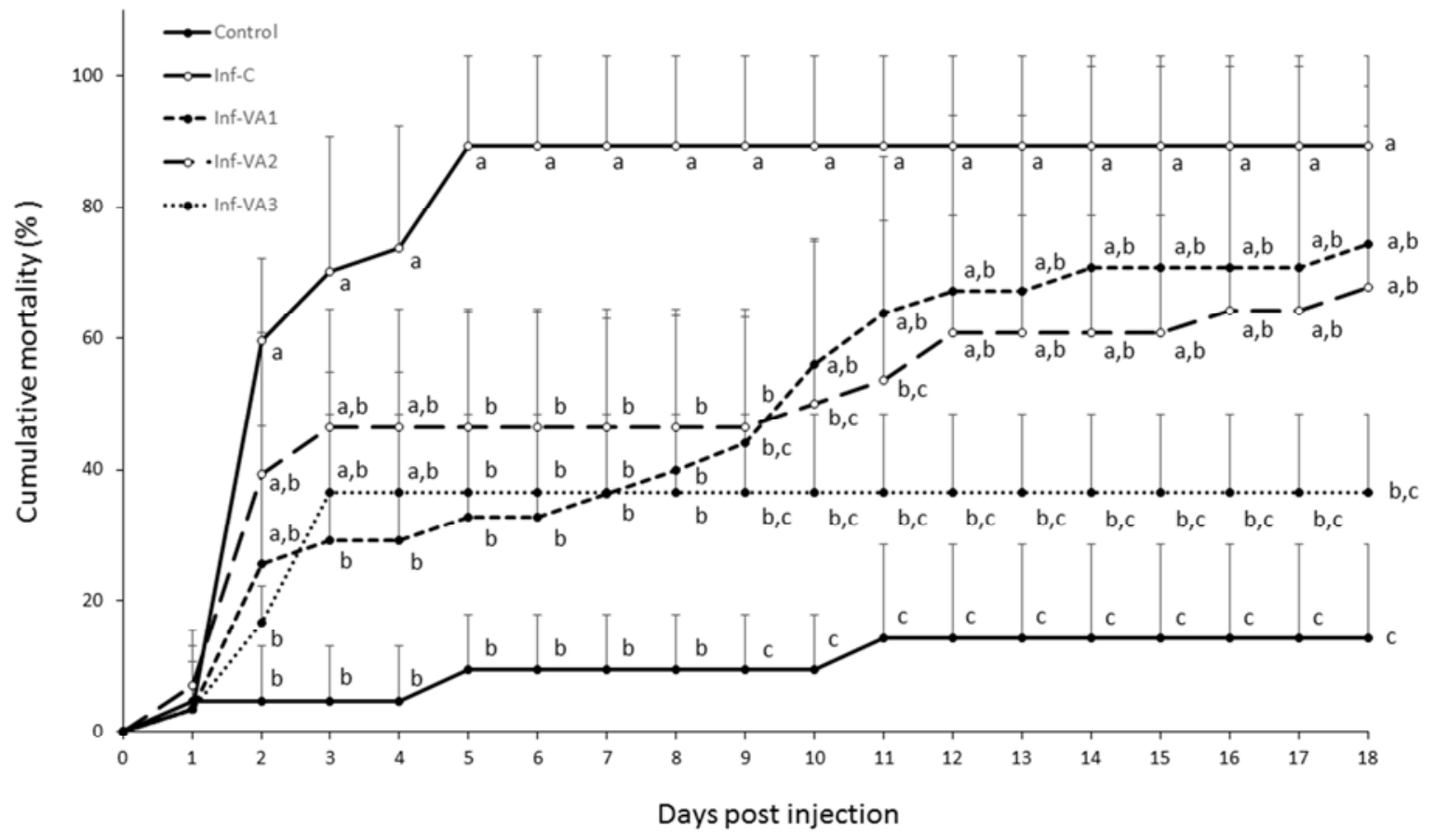




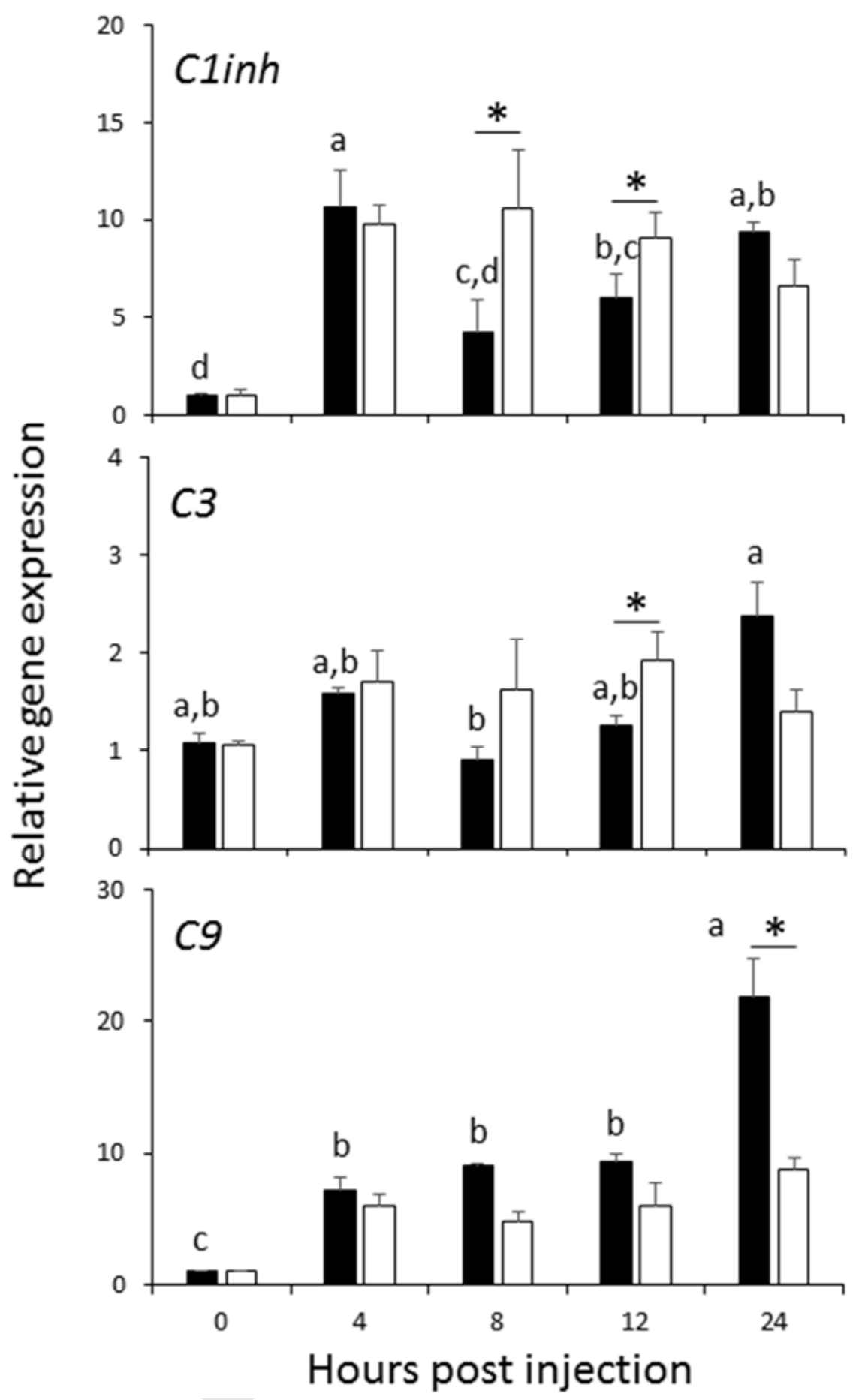




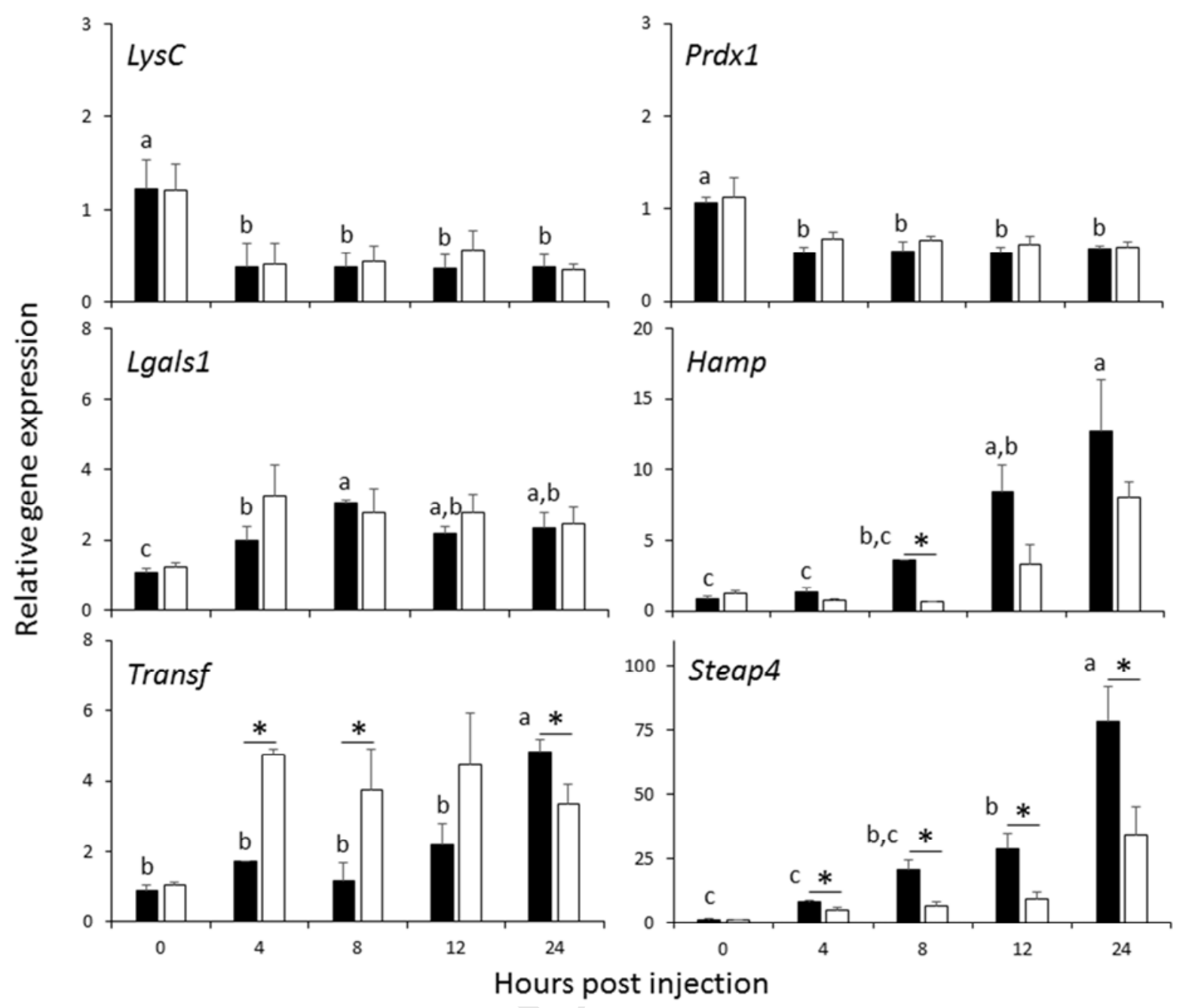




\section{Highlights}

- Dietary vitamin A (VA) enhances immune system in Solea senegalensis juveniles

- Sole fed $203,000 \mathrm{VA} \mathrm{IU} \mathrm{Kg}^{-1}$ had higher resistance to an induced bacterial infection

- Complement system and iron homeostasis genes were differentially expressed

- Dietary VA levels impact on the fish osteoimmunological response 
Supplementary Table S1. Gene name, accession numbers (GenBank or Unigene), primers and expected amplicon size used to perform the relative gene expression quantification in Senegalese sole (Solea senegalensis) early juveniles and confirming DNA Photobacterium damselae subsp. damselae presence in injected fish.

\begin{tabular}{|c|c|c|c|c|}
\hline Gene name & Accession numbers* & Component & 5' to 3' nucleotide sequences & $\begin{array}{l}\text { Expected amplicon } \\
\text { size (bp) }\end{array}$ \\
\hline C1inh & $\begin{array}{l}\text { unigene64193 } \\
\text { unigene526786 }\end{array}$ & $\begin{array}{l}\text { Forward } \\
\text { Reverse }\end{array}$ & $\begin{array}{l}\text { ACCTGTGTGGCCTCTCCCCTG } \\
\text { ACTGGTAGCAGCAGCAGCCT }\end{array}$ & 107 \\
\hline C3 & FJ345403 & $\begin{array}{l}\text { Forward } \\
\text { Reverse }\end{array}$ & $\begin{array}{l}\text { GGCTTACTAACTGGCTTCACTGTCA } \\
\text { CCTCTCTCTGACAGAACTGTGTCCA }\end{array}$ & 110 \\
\hline C9 & $\begin{array}{l}\text { unigene430267 } \\
\text { unigene2945 }\end{array}$ & $\begin{array}{l}\text { Forward } \\
\text { Reverse }\end{array}$ & $\begin{array}{l}\text { ATCAGGAGGGTAACTGGACATGCTG } \\
\text { GCCCCACTCAGTCCGTCTGTGT }\end{array}$ & 100 \\
\hline Lgals1 & $\begin{array}{l}\text { unigene27503 } \\
\text { unigene94321 }\end{array}$ & $\begin{array}{l}\text { Forward } \\
\text { Reverse }\end{array}$ & $\begin{array}{l}\text { TGACTCAGACAACATCGCAATGCAC } \\
\text { CACCCCAGCATCCCCCGGAC }\end{array}$ & 101 \\
\hline Hamp & $\begin{array}{l}\text { FJ263548 } \\
\text { AB455099 }\end{array}$ & $\begin{array}{l}\text { Forward } \\
\text { Reverse }\end{array}$ & $\begin{array}{l}\text { ACACTCGTGCTCGCCTTTGTTTGCTTC } \\
\text { TGACTCCAGCGTCTGTGTCTGACATGATTC }\end{array}$ & 173 \\
\hline LysC & DQ293993 & $\begin{array}{l}\text { Forward } \\
\text { Reverse }\end{array}$ & $\begin{array}{l}\text { AGCAGCTTAGGGAGAGAGACCGTC } \\
\text { TGTTGATCTGGAAGATGCC }\end{array}$ & 254 \\
\hline Prdx1 & $\begin{array}{l}\text { unigene65476_split_1 } \\
\text { unigene281027 }\end{array}$ & $\begin{array}{l}\text { Forward } \\
\text { Reverse }\end{array}$ & $\begin{array}{l}\text { ACGGAGTGCTGAAGGAGGACGA } \\
\text { CCACAGAGCGACCCACAGGT }\end{array}$ & 114 \\
\hline Steap4 & FJ263550 & $\begin{array}{l}\text { Forward } \\
\text { Reverse }\end{array}$ & $\begin{array}{l}\text { CTGGGACTGCTGGCACTTGGATTTG } \\
\text { CAGTTCTCCACGCTGACGTACTGTCGAAC }\end{array}$ & 160 \\
\hline Transf & FJ345407 & $\begin{array}{l}\text { Forward } \\
\text { Reverse }\end{array}$ & $\begin{array}{l}\text { TGCAGGGCTGGAACATTCCCATA } \\
\text { GCCCCGAAAAATGCACGCACG }\end{array}$ & 109 \\
\hline$U b q$ & AB291588 & $\begin{array}{l}\text { Forward } \\
\text { Reverse }\end{array}$ & $\begin{array}{l}\text { AGCTGGCCCAGAAATATAACTGCGACA } \\
\text { ACTTCTTCTTGCGGCAGTTGACAGCAC }\end{array}$ & 93 \\
\hline $\begin{array}{l}\text { 16S-like ssrDNA } \\
\text { degenerate }\end{array}$ & & $\begin{array}{l}\text { Forward } \\
\text { Reverse }\end{array}$ & $\begin{array}{l}\text { AGAGTTTGATCMTGGCTCAG } \\
\text { AAGGAGGTGATCCANCCRCA }\end{array}$ & 1424 \\
\hline
\end{tabular}

*GeneBank and/or Solea Data Base (http://www.juntadeandalucia.es/agriculturaypesca/ifapa/aquagenet/soleaDB $)$ (solea_v4.1) 


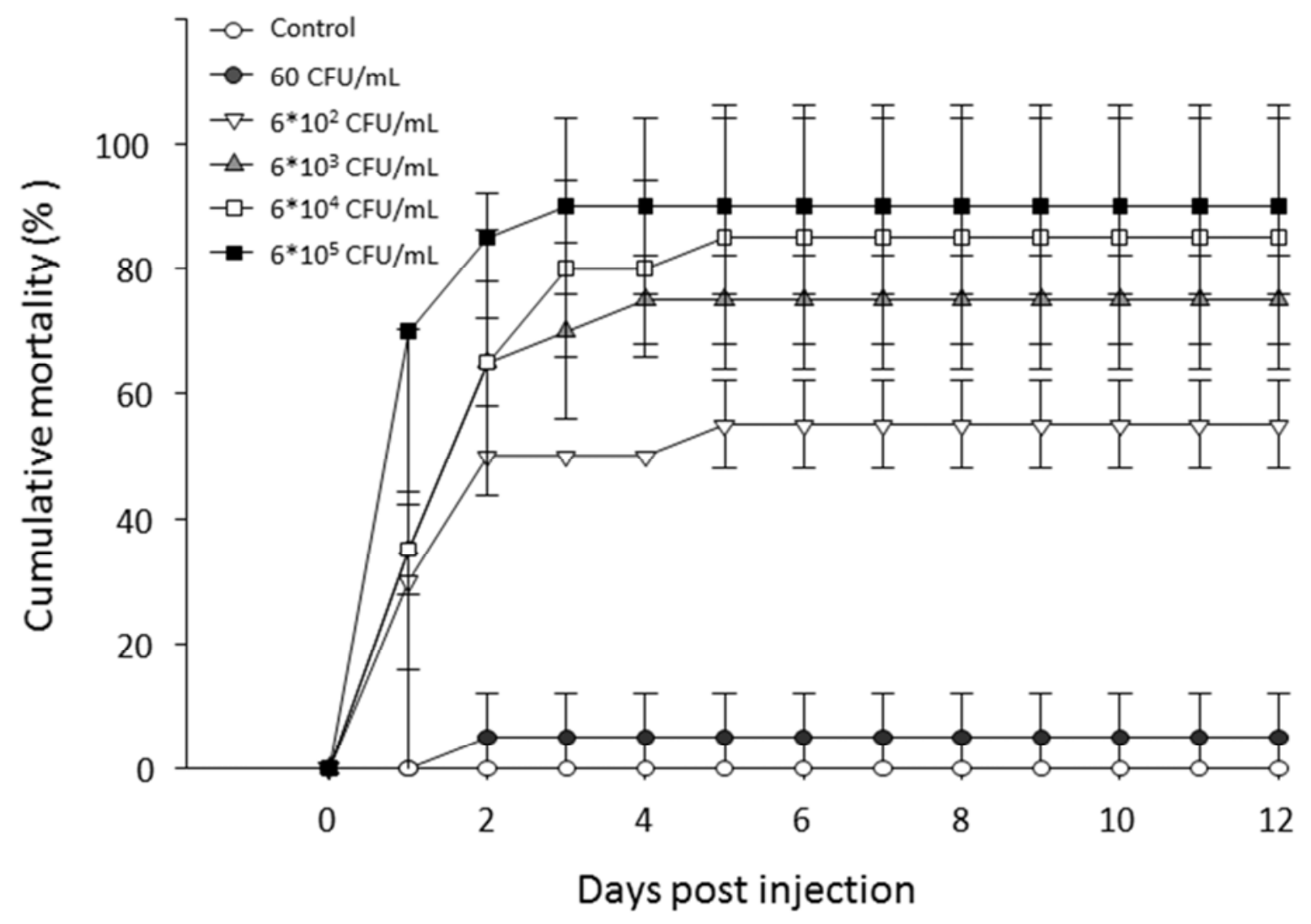




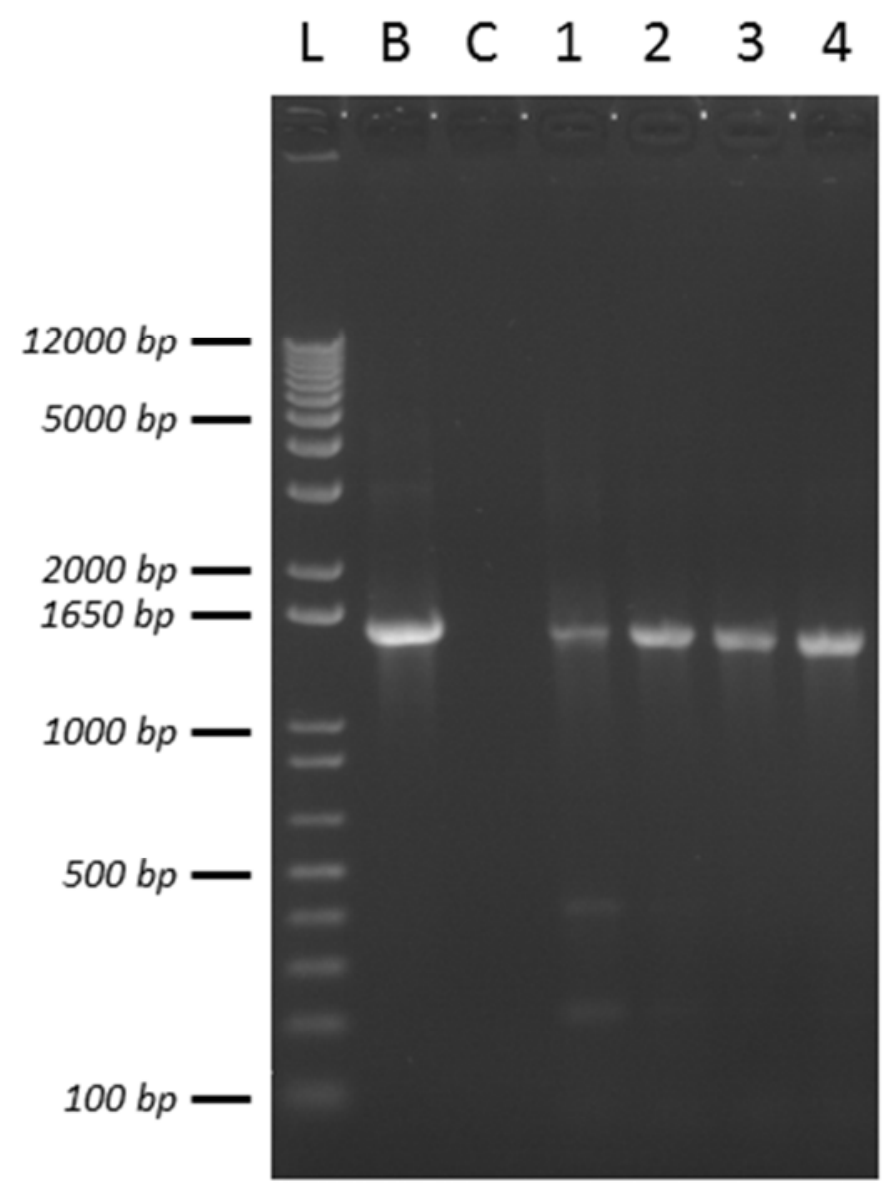

